ISSN 0258-7122 (Print), 2408-8293 (Online)

Bangladesh J. Agril. Res. 43(2): 187-203, June 2018

\title{
SOCIO-ECONOMIC PERFORMANCE OF BT EGGPLANT CULTIVATION IN BANGLADESH
}

\author{
M. A. RASHID ${ }^{1}$, M. K. HASAN ${ }^{2}$ AND M. A. MATIN ${ }^{3}$
}

\begin{abstract}
A study was conducted in 35 districts of Bangladesh during 2016-17 winter season for assessing the farm level performance of $B t$ eggplant in reducing pesticide use, cultivation cost and increase farm income. Five hundred five $B t$ eggplant farmers were selected purposively and 350 non- $B t$ eggplant farmers were selected randomly for the study. Net returns per hectare were Tk. 179,602/ha for $B t$ eggplant as compared to Tk. 29,841/ha for non-Bt eggplant. Pesticides were applied 11 times to $B t$ eggplant where as it was 41 times to non$B t$ eggplant for controlling sucking pests. The $B t$ eggplant farmers saved 61 percent of the pesticide cost compared to non-Bt eggplant farmers, experienced no losses due to fruit and shoot borer, and received higher net returns. The experience with $B t$ eggplant technology was good for most of the locations and up to the mark and off course this technology will be significantly improved to their socio-economic conditions in future as reported by the $B t$ respondents. All $B t$ and $86 \%$ non- $B t$ farmers wanted to cultivate $B t$ eggplant in the next year if they can obtain the seeds/seedlings from the research station. For getting higher yield and economic benefits, in the course of technology dissemination, the importance of good production practices must be emphasized.
\end{abstract}

Keywords: economics, pesticides, farm income and eggplant.

\section{Introduction}

Eggplant (Solanum melongena L.) is one of the most important vegetables cultivated and consumed in Bangladesh (Saifullah et al., 2012). Also known as brinjal and aubergine, the quantity consumed ranks third after potato among vegetables in the country and its consumption and price have grown over time. It is produced on approximately 50,000 hectares and by about 150,000 farmers (BBS, 2014). Due in part to the prevalence of insect pests and diseases, the eggplant productivity in Bangladesh is the lowest in the world (Choudhary and Gaur, 2009). Available data at the national level indicate that eggplant yield is currently about eight tons per ha in Bangladesh (BBS, 2014). Despite modest progress in raising yields through improved cultivation techniques and varietal resistance to diseases, eggplant productivity could be raised substantially if the crop's major insect pest, the fruit and shoot borer (FSB, Leucinodes orbonalis), could be managed effectively. Over the years, the area under eggplant

${ }^{1}$ Principal Scientific Officer, Agricultural Economics Division, ${ }^{2}$ On-Farm Research Division and ${ }^{3}$ Chief Scientific Officer, Agricultural Economics Division, Bangladesh Agricultural Research Institute (BARI), Gazipur-1701, Bangladesh. 
production, both in summer and winter season, has declined significantly compared to other vegetablesbecause of the significant losses caused by the FSB (Choudhary et al., 2014).

FSB causes losses of up to 70 percent in commercial plantings. It is estimated that the FSB alone reduces marketable produce by about two-thirds (ABSP-II, 2007; Rahman et al., 2009). As a result, farmers are left with little choice except controlling it with insecticides, which are often ineffective as the pest bores into the fruit. Farmers often apply insecticides every other day, or up to 80 sprays per season, at a steep monetary ( $\$ 180$ hectare) and environmental/health cost (Meherun nahar and Paul, 2009). A study of the impact of FSB in Jessore district of Bangladesh indicated that 98 percent of the farmers relied exclusively on pesticides to manage it, with more than 60 percent of farmers spraying their crop 140 times or more per season (Alam et al., 2003). Such use of pesticide is not common in all districts of Bangladesh. Similar to Jessore study, other studies are necessary for various districts to determine the number of spraying in non- $B t$ eggplant for controlling FSB by the farmers. Pesticides alone contribute to one third of the total cost of production of eggplant and farmer and consumer exposure to chemical insecticides (Choudhary and Gaur, 2009). Despite frequent use of insecticides, farmers still experience significant yield losses due to FSB.

Table 1.Area, production and yield of Kharif and Rabi eggplant in Bangladesh

\begin{tabular}{c|cccc}
\hline Year & Area ('000 ha) & Production ('000 MT) & Yield (t/ha) \\
\hline Kharif season: & & & \\
$2007-08$ & 18.40 & 122.73 & 6.67 \\
$2008-09$ & 18.10 & 123.78 & 6.84 \\
$2009-10$ & 17.96 & 125.08 & 6.96 \\
$2010-11$ & 17.92 & 124.38 & 6.94 \\
$2011-12$ & 16.84 & 126.99 & 7.54 \\
Rabi season: & & & \\
$2007-08$ & 29.35 & 215.28 & 7.33 \\
$2008-09$ & 28.28 & 213.79 & 7.56 \\
$2009-10$ & 28.75 & 216.18 & 7.52 \\
$2010-11$ & 28.63 & 215.41 & 7.52 \\
$2011-12$ & 27.54 & 224.04 & 8.14 \\
\hline
\end{tabular}

Source: BBS (2014).

In recent years, the productivity of eggplant slightly increased. The data available in national level indicated that during 2011-12 the yield of kharif season eggplant was 7.54 ton per hectare and that of rabi season eggplant was 8.14 ton per hectare with about one ton per hectare yield increment from previous five years (BBS, 2014) (Table 1). Despite the decreasing trends of area in both kharif and rabi 
season, increasing trend of total production was observed mainly due to adoption of high yielding varieties. In spite of some progress in improving the productivity of eggplant in Bangladesh through new vegetable cultivation techniques, recent studies have shown that the productivity of eggplant could be more than tripled in Bangladesh by growing genetically modified eggplant (Bt eggplant) with resistance to brinjal shoot and fruit borer.

Price of eggplant fluctuates among the growing seasons (Figure 1.1). It is also observed that average eggplant price gradually increased over the last few years.
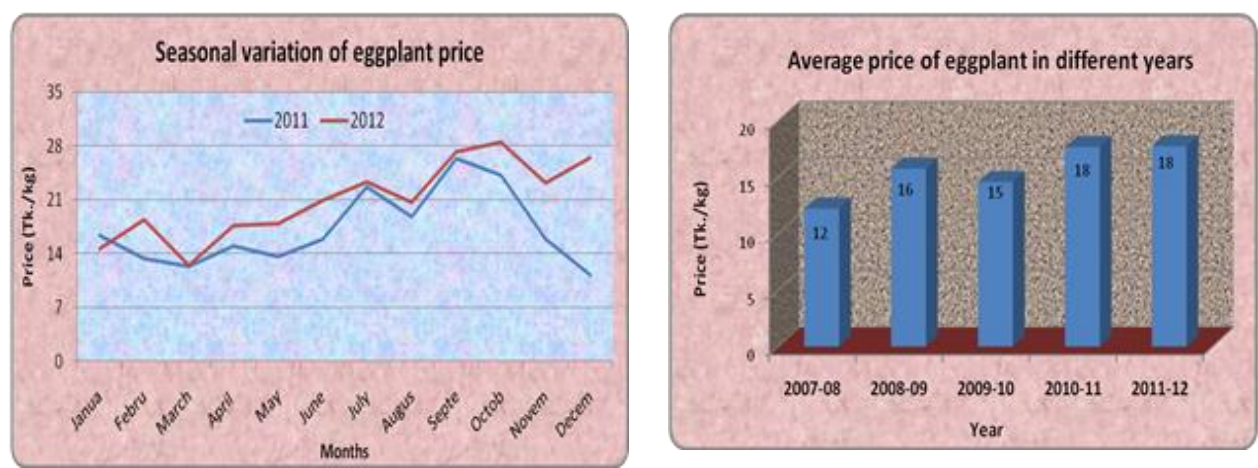

Figure 1.1 Price variation of eggplant in Bangladesh

\section{Development of $B t$ eggplant}

A potential solution to control eggplant Fruit and Shoot Borer (FSB) is $B t$ eggplant, a genetically modified eggplant that carries an additional gene that provides built-in protection against the insect pest. This transgenic eggplant was created by inserting a crystal protein gene, Cry $1 A c$, which expresses an insecticidal protein to confer resistance against FSB. The Cry 1 Ac gene is sourced from an environmentally friendly and ubiquitous soil bacterium called Bacillus thuringiensis (Bt), which has been used as a biological pest control in granular or powder form for many years. The Cry 1 Ac gene along with two other supporting genes, nptII and aad, are combined such that they work together to produce an insecticidal protein that is toxic to FSB (Choudhary and Gaur, 2009).

The Agricultural Biotechnology Support Project II (ABSP-II) at Cornell University facilitated the transfer of Bt eggplant event EE-1 from an Indian seed company, Mahyco, to BARI (ABSP-II, 2007; ABSP-II, 2014). BARI then introgressed Bt eggplant event EE-1 into locally adapted and commercially popular openpollinated eggplant varieties of Bangladesh. Out of the nine popular varieties that were introgressed with $\mathrm{Bt}$ event EE-1, four were approved for commercial cultivation in October 2013. The released varieties were BARI Bt Begun-1, BARI Bt Begun-2, BARI Bt Begun-3 and BARI Bt Begun-4. The Bt varieties underwent seven years of greenhouse and field trials in various geographic locations in Bangladesh to test their efficacy and environmental safety. 


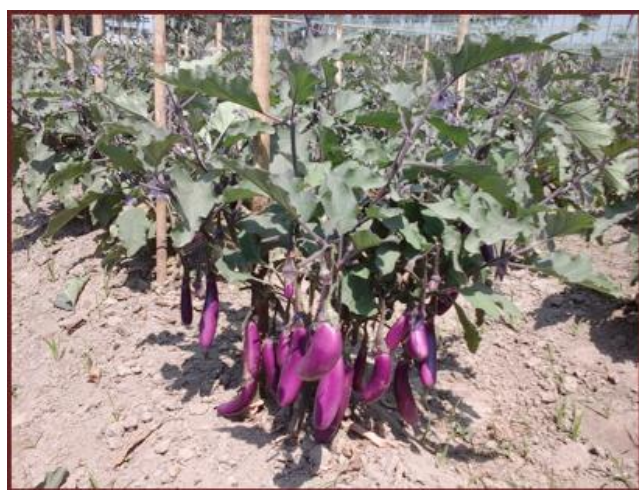

BARI Bt Begun-1

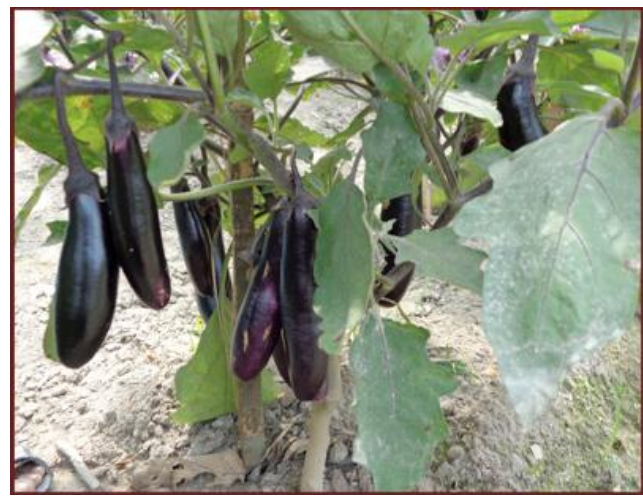

BARI Bt Begun-3

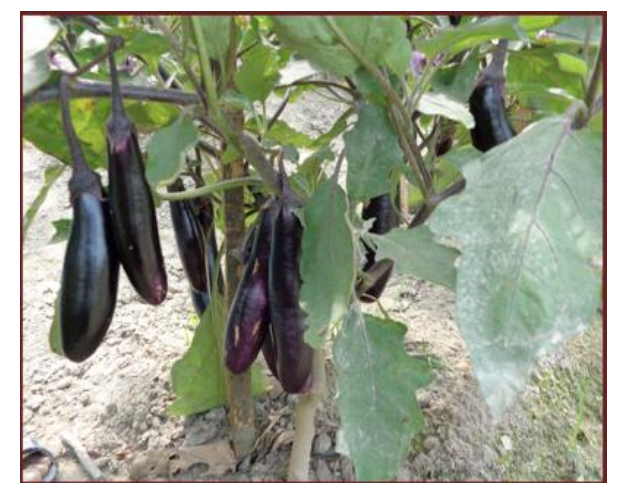

BARI Bt Begun-2

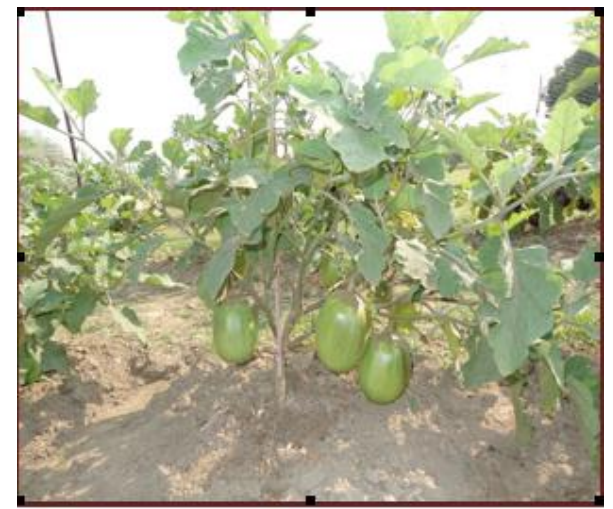

BARI Bt Begun-4

$B t$ eggplant was subjected to standard food and environmental safety tests in the standard national and accredited foreign laboratories (ref). The nutritional composition of $B t$ eggplant was the same as that of non-Bt (conventional) eggplant. The new $B t$ varieties are self-pollinating and therefore farmers can save their seeds and reuse them. Experiments conducted at various stations of BARI have found that the $B t$ varieties reduce FSB infestation and the number of insecticide applications and improve yield. With no reports of any detrimental effect on human health, bio-diversity, and environment, the technology was approved for commercial release.

\section{Objectives}

This study was undertaken to evaluate the performance of $B t$ eggplant during the 2016-17 winter season, with a focus on pesticide use as a potential impact of $B t$ eggplant is the health and environmental benefits due to reduced pesticide use.

The specific objectives of the study are to: 
1. To assess the level of BSFB and sucking pests infestation and their control in $B t$ eggplant cultivation

2. To estimate the profitability of $B t$ eggplant as compared to non-Bt eggplant cultivation and

3. To evaluate the impacts of $B t$ technologies on input use, productivity and profitability

\section{Materials and Methods}

\subsection{Study areas}

The study was undertakenthirty five districts in Bangladesh viz.,Dinajpur, Rangpur, Kurigram, Bogra, Joypurhat, Gaibandha, Rajshahi, Pabna, Khulna, Kushtia, Jessore, Meherpur, Chuadanga, Satkhira, Barisal, Patuakhali, Bhola, Gopalganj, Faridpur, Rajbari, Madaripur, Gazipur, Sherpur, Kishoreganj, Mymensingh, Tangail, Manikgonj, Narshingdi, Munshiganj, Chittaganj, Comilla, Feni, Bandarban, Cox' Bazer and Sylhet where Bt eggplant varieties were planted in farmers' fields.

\subsection{Sample size}

The sample farmers were both $B t$ and non-Bt eggplant together constituted 855 farmers. $B t$ farmers refers to those farmers who cultivated eggplant during Rabi 2016-17 season by using seedlings of $B t$ eggplant distributed by BARI. Non-Bt farmers are the traditional eggplant producers and they were selected fromthe same locations cultivating same varietiesfor comparative analysis.Data were collected from 505Bt eggplant growers and 350 non-Bt eggplant growers. The survey covered 105 villages from the selected districts. Face to face interview technique was followed to collect the primary data from the selected farmers. A pre-designed and pre-tested interview schedule was used for this purpose.

\subsection{Analytical techniques}

The farm-level survey data collected were checked, summarized, and analyzed. Descriptive statistics were provided with comparison of means, and budgets were calculated to assess economic benefits.

\section{Measurement of financial costs and returns}

In this study, costs and returns analyses will be done on both variable and total cost basis. The following equation ( $\Pi$ ) will be used to assess the financial profitability of eggplant cultivation.

$$
\Pi=\sum_{i=1}^{n} \mathrm{P}_{\mathrm{i}} \mathrm{Q}_{\mathrm{i}}-\mathrm{TC}=\sum_{i=1}^{n} \mathrm{P}_{\mathrm{i}} \mathrm{Q}_{\mathrm{i}}-(\mathrm{VC}+\mathrm{FC})
$$


Where,

$$
\begin{aligned}
& \Pi=\text { Profit or value addition from eggplant production } \\
& Q_{i}=\text { Quantity of eggplant of } i^{\text {th }} \text { farmers }(\mathrm{kg} / \mathrm{ha}) \\
& \mathrm{P}_{\mathrm{i}}=\text { Average price of eggplant of } \mathrm{i}^{\text {th }} \text { farmers }(\mathrm{Tk} / \mathrm{kg}) \\
& \mathrm{TC}=\text { Total cost }(\mathrm{Tk} / \mathrm{ha}) \\
& \mathrm{VC}=\text { Variable cost }(\mathrm{Tk} / \mathrm{ha}) \\
& \mathrm{FC}=\text { Fixed cost }(\mathrm{Tk} / \mathrm{ha}) \\
& \mathrm{i}=1,2,3, \ldots \ldots . . ., \mathrm{n}
\end{aligned}
$$

Per hectare profitability of growing eggplant from the view points of individual farmers was measured in terms of gross return, gross margin and net return.

Gross return: Gross return was calculated by simply multiplying the total volume of output with it's per unit of price in the harvesting period.

Gross margin: Gross margin calculation was done to have an estimate of the difference between total return and variable costs. The argument for using the gross margin analysis is that the farmers of Bangladesh are more interested to know their return over variable costs.

Net return: The analysis considered fixed cost (which included lend rent and family supplied labour). Net margin was calculated by deducting all costs (Variable and Fixed) from gross return.

\section{Results and Discussion}

\subsection{Socioeconomic characteristics of the sample farmers}

Socio-economic characteristics of the eggplant farmers in the survey are reported in Table 2.

The $B t$ eggplant growers was slightly younger on average than the non- $B t$ eggplant growers. Most of the $B t$ and non-Bt farmers belonged to the age group $31-45$ (46\% and $48 \%$ respectively) and age group 46-60 years (34\% and $40 \%$ respectively). Most of the farmers had at least primary level education, most $B t$ eggplant farmers had at least secondary level education, and, on-average, $B t$ eggplant growers were more educated than non- $B t$ growers. Non- $B t$ farmers had, on average, more years of eggplant cultivation experience and slightly larger households. Average hectares of land owned by $B t$ and non- $B t$ farmers were 0.816 and 0.477 ha respectively. However, $B t$ farmers rented in landmore than that of non- $B t$ farmers. 
Table 2. Summary socioeconomic statistics for eggplant growers in sample

\begin{tabular}{lcc}
\hline & Bt farmers & Non-Bt farmers \\
\hline Sample size (No.) & 505 & 350 \\
Farmers age (\%) & & \\
$\quad$ Below 30 years & 15 & 5 \\
31-45 years & 46 & 48 \\
46-60 years & 34 & 40 \\
$\quad$ Above 60 years & 5 & 7 \\
Level of Education (\%) & & \\
Illiterate & 12 & 27 \\
Primary & 32 & 50 \\
Secondary & 36 & 23 \\
Above secondary & 18 & - \\
Eggplant cultivation experience (\%) & & 40 \\
1-5 years & 54 & 46 \\
6-10 years & 28 & 7 \\
11-15years & 7 & 4 \\
16-20 years & 3 & 3 \\
Above 20 years & 8 & 6.477 \\
Household size (No.) & 5 & 0.254 \\
Land farmed (hectare) & & 0.014 \\
Owned land & 0.816 & \\
Leased in & 0.448 & \\
Leased out & 0.087 & \\
\hline
\end{tabular}

\subsection{Level of BSFB infestation and their control in eggplant cultivation}

It was interesting that the BSFB infestation in shoot 1.44 percent (ranged from 0.27-3.88 \%) and in fruit (by no.) $2.00 \%$ (range from 0.21-4.17\%) along with infestation in fruit (by wt.) $1.90 \%$ (varied from 0.29-3.55\%) in $B t$ eggplant whereas $25.18 \%$ shoot and $49.37 \%$ fruit (by no.) as well as $51.88 \%$ fruit (by wt.) infestation in non- $B t$ counterpart in the study areas. On the other hand, $87 \%$ of $B t$ farmers and $97 \%$ of non- $B t$ farmers mentioned about infestation by the sucking pests in eggplant cultivation (Table 3). 
Table 3. Infestation by BSFB and sucking pests in the study areas

\begin{tabular}{|c|c|c|c|c|c|c|}
\hline & \multicolumn{3}{|c|}{ Bt farmers } & \multicolumn{3}{|c|}{ Non-Bt farmers } \\
\hline & \multicolumn{3}{|c|}{ BSFB infestation (\%) } & \multicolumn{3}{|c|}{ BSFB infestation (\%) } \\
\hline Region & Shoot & Fruit (by no.) & Fruit (by wt.) & Shoot & Fruit (by no.) & Fruit (by wt.) \\
\hline Rangpur & 0.27 & 0.59 & 0.63 & 25.85 & 49.83 & 49.12 \\
\hline Rajshahi & 0.69 & 1.24 & 1.22 & 23.14 & 48.79 & 52.18 \\
\hline Khulna & 0.68 & 2.94 & 2.53 & 25.81 & 40.56 & 44.89 \\
\hline Barisal & 1.73 & 0.21 & 0.29 & 26.54 & 51.49 & 55.45 \\
\hline Dhaka & 1.41 & 2.84 & 3.55 & 24.15 & 50.12 & 53.15 \\
\hline Chittaganj & 3.88 & 4.17 & 3.15 & 25.56 & 55.45 & 56.47 \\
\hline All & 1.44 & 2.00 & 1.90 & 25.18 & 49.37 & 51.88 \\
\hline Range & $0.27-3.88$ & $0.21-4.17$ & $0.29-3.55$ & $23.14-26.54$ & $40.56-55.45$ & $49.12-56.47$ \\
\hline \multicolumn{7}{|c|}{ Sucking pest infestation (\%) } \\
\hline & \multicolumn{3}{|c|}{87} & \multicolumn{3}{|c|}{97} \\
\hline
\end{tabular}

To protect eggplant from the pests, both $B t$ and non- $B t$ farmers of the selected areas applied several pesticides (Table 4). The specific pesticides applied and the percent of $B t$ eggplant and non-Bt eggplant farmers reporting their applications were for aphids, jassids, whiteflies, epilachna beetles, thrips, and red mites were: Admire (51\% and 67\%), Sevin 85SP (18\% and 22\%), Dasban (around 15\% and 25\%), Marshal 20EC (around 14\% and 32\%), Actara 25WG (10\% and 35\%), Tundra (around 9\% and 20\%), Vertimax (6\% and14\%), Volume Flexi (5\% and $10 \%)$, and Kinolux $(5 \% \& 10 \%)$. For FSB, only non-Bt farmers applied pesticides, and the specific products used were: Suntaf 50SP (by $65 \%$ of the non- $B t$ farmers), Emituf 50SP (45\%), Ostad 10EC (40\%), Corolux (32\%), Marshal 20EC $(28 \%)$, Sumithion (22\%), and Tufgor 40EC (15\%).

Most $B t$ and non-Bt eggplant farmers visit their fields and scout for pest infestation levels before spraying. The $B t$ farmers reported no attacks by FSB in their fields and therefore did not spray. Most non-Bt farmers assumed that beneficial insect populations probably decrease in their fields due to pesticide sprays for FSB. $B t$ farmers sprayed only for sucking pests than did non-Bt eggplant farmers even though the number of farmers who reported sucking pests was similar for the two groups of farmers. All of the $B t$ eggplant farmers and all of the non- $B t$ eggplant farmers reported home consumption of $B t$ eggplant, the latter even though the eggplants were heavily sprayed. All of the $B t$ and most $(86 \%)$ the non- $B t$ farmers said they would be willing to adopt $B t$ technology in the coming year if they can obtain the seeds/seedlings. 
Table 4. Brand names of pesticides and targeted pests for eggplant cultivation

\begin{tabular}{l|l|c|c}
\hline \multirow{2}{*}{ Targeted pests } & \multirow{2}{*}{ Names of pesticides used } & \multicolumn{2}{|c}{ Farmer responded (\%) } \\
\cline { 3 - 4 } & & Bt farmers & Non-Bt farmers \\
\hline Aphid, Jassid, & Admire & 51 & 67 \\
Whitefly, & Sevin 85SP & 18 & 22 \\
Epilachna beetle, & Dasban & 15 & 25 \\
Thrips, Red mite & Marshal 20EC & 14 & 32 \\
& Actara 25WG & 10 & 35 \\
& Tundra & 9 & 20 \\
& Vertimax & 6 & 14 \\
& Volume Flexi & 5 & 10 \\
Brinjal shoot & Kinolux & 5 & 10 \\
fruit borer & Suntaf 50SP & - & 65 \\
& Emituf 50SP & - & 45 \\
& Ostad10EC & - & 40 \\
& Corolux & - & 32 \\
& Marshal 20EC & - & 28 \\
& Sumithion & - & 22 \\
& Tafgor 40EC & - & 15 \\
\hline
\end{tabular}

Table 5. Per hectare input use on eggplant in the study areas

\begin{tabular}{|c|c|c|}
\hline \multirow{2}{*}{ Items } & \multicolumn{2}{|c|}{ Input use } \\
\hline & Bt farmer & Non-Bt farmer \\
\hline \multicolumn{3}{|l|}{ Human labour (man-days): } \\
\hline Family & 147 & 156 \\
\hline Hired & 190 & 256 \\
\hline Mechanical power (Tk.) & 10685 & 11126 \\
\hline \multicolumn{3}{|l|}{ Fertilizers $(\mathrm{kg})$ : } \\
\hline Farmyard manure & 11225 & 15624 \\
\hline Urea & 335 & 415 \\
\hline TSP & 239 & 398 \\
\hline $\mathrm{MoP}$ & 245 & 320 \\
\hline DAP & 46 & 56 \\
\hline Gypsum & 107 & 146 \\
\hline Zinc sulphate & 10 & 24 \\
\hline Boric Acid & 10 & 18 \\
\hline Seedling (no.) & 6916 & 9535 \\
\hline Irrigation (no.) & 6 & 8 \\
\hline Weeding (no.) & 4 & 6 \\
\hline Spray (no.) & 11 & 41 \\
\hline Harvest (no.) & 21 & 26 \\
\hline
\end{tabular}




\subsection{Input use and costs}

Input usage for cultivation of $B t$ and non- $B t$ eggplant is summarized in Table 5. Most of the non-Bt farmers purchased seedlings for their cultivation. $B t$ farmers used seedlings that supplied from the government research farms free of cost. However, the cost of $B t$ eggplant seedlings was considered the same as the cost of non-Bt seedlings for purposes of this study. On average, non-Bt farmers applied fertilizers at higher rates than non- $B t$ farmers, perhaps due to instructions when $B t$ seedlings were delivered. Non- $B t$ farmers also applied more labor due to the additional pesticide and fertilizer applications. Non- $B t$ farmers applied insecticides 41 times and the $B t$ farmers applied insecticides 11 times (only for other pest control) during crop cultivation.

Table 6. Per hectare cost ofeggplant production in the study areas

\begin{tabular}{l|c|c}
\hline \multirow{2}{*}{\multicolumn{1}{c}{ Items }} & \multicolumn{2}{c}{ Cost of cultivation (Tk./ha) } \\
\cline { 2 - 3 } A. Variable cost: & $\boldsymbol{B}$ farmer & Non- $\boldsymbol{B t}$ farmer \\
Human labour (Hired) & $46800(21.77)$ & $69000(24.37)$ \\
Mechanical power & $8982(4.18)$ & $11227(3.97)$ \\
Fertilizers: & & \\
Farm yard manure & $11225(5.22)$ & $15624(5.52)$ \\
Urea & $5360(2.49)$ & $6640(2.35)$ \\
TSP & $5736(2.67)$ & $7680(2.71)$ \\
MoP & $3920(1.82)$ & $5120(1.81)$ \\
Gypsum & $1070(0.50)$ & $1460(0.52)$ \\
Zinc sulphate & $2000(0.93)$ & $4200(1.48)$ \\
Boric Acid & $4000(1.86)$ & $6000(2.12)$ \\
Furadan & $3750(1.74)$ & $0(0.00)$ \\
Bleching powder & $3000(1.40)$ & $0(0.00)$ \\
Seedling & $6916(3.22)$ & $8535(3.01)$ \\
Irrigation & $14820(6.89)$ & $19760(6.98)$ \\
Pesticides & $14215(6.61)$ & $36057(12.74)$ \\
Support and netting & $11030(5.13)$ & $15570(5.50)$ \\
Interest on operating capital & $3095(1.44)$ & $4482(1.58)$ \\
Total variable cost & $\mathbf{1 4 5 9 1 9 ( 6 7 . 8 8 )}$ & $\mathbf{2 1 1 3 5 5}(\mathbf{7 4 . 6 6})$ \\
B. Fixed cost: & & \\
Rental value of land & $24949(11.61)$ & $24949(8.81)$ \\
Family labour & $44100(20.51)$ & $46800(16.53)$ \\
Total fixed cost & $\mathbf{6 9 0 4 9 ( 3 2 . 1 2 )}$ & $\mathbf{7 1 7 4 9}(\mathbf{2 5 . 3 4})$ \\
Total cost (A+B) & $\mathbf{2 1 4 9 6 8 ( 1 0 0 )}$ & $\mathbf{2 8 3 1 0 4}(\mathbf{1 0 0})$ \\
\hline
\end{tabular}

Figures in the parenthesis indicate percent of total cost 


\subsection{Cost of eggplant production}

The cost of production, including cash expenses and imputed family labor costs, are shown in Table 5. Higher variable costs were recorded with the non-Bt farmers due to higher use of labour, fertilizer, and pesticides. Human labour was the largest cost item for both $B t$ and non- $B t$ farmers followed by fertilizer and pesticides (Table 6). Pesticide cost of non-Bt eggplant was more than three times higher compared to $B t$ eggplant. The total variable costs of $B t$ and non- $B t$ eggplant cultivation were Tk. 145,919 per hectare and Tk. 211,335 per hectare respectively. The total cost of (variable costs and fixed costs) Bt eggplant cultivation was Tk. 214,968 per hectare whereas it was Tk. 283,104 per hectare for non-Bt eggplant.

Table 7. Regional yield of $B t$ and non- $B t$ eggplant varieties during winter 2016-17

\begin{tabular}{|c|c|c|c|c|c|c|c|c|c|c|}
\hline \multirow[b]{3}{*}{ Region } & \multicolumn{10}{|c|}{ Yield (t/ha) } \\
\hline & \multirow[b]{2}{*}{ 总 } & \multirow{2}{*}{ 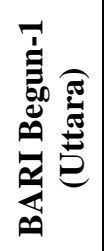 } & \multirow[b]{2}{*}{ 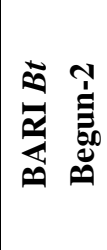 } & \multirow{2}{*}{ 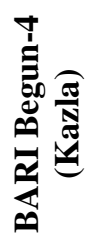 } & \multirow[b]{2}{*}{ 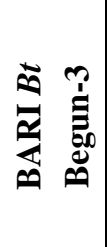 } & \multirow{2}{*}{ 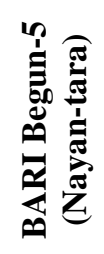 } & \multirow[b]{2}{*}{ 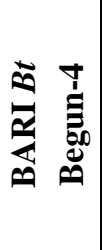 } & \multirow{2}{*}{ 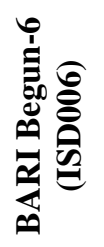 } & \multicolumn{2}{|c|}{ All } \\
\hline & & & & & & & & & 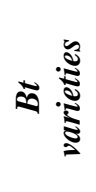 & 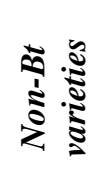 \\
\hline angpur & - & - & 22.35 & - & - & 22.48 & 24.92 & - & 23.64 & 22.48 \\
\hline Rajshahi & 17.68 & 13.59 & 30.28 & 24.86 & - & 17.35 & 29.31 & 22.65 & 25.76 & 19.52 \\
\hline Khulna & - & - & 24.72 & 23.28 & 17.35 & 16.33 & 18.29 & 16.88 & 20.12 & 18.83 \\
\hline arisal & - & - & 26.60 & 21.54 & 27.24 & 15.33 & 19.56 & 16.25 & 24.47 & 17.71 \\
\hline Dhaka & - & - & 24.23 & 22.62 & 19.62 & 17.38 & 22.30 & - & 22.05 & 20.00 \\
\hline Chittagong & - & - & 27.79 & 25.28 & 20.17 & - & 21.69 & 19.87 & 23.22 & 22.58 \\
\hline All & 17.68 & 14.39 & 26.00 & 23.52 & 21.10 & 17.77 & 22.68 & 18.91 & 23.21 & 20.19 \\
\hline
\end{tabular}

Note: $B t$ eggplant event $E E-1$ was introgressed into four open pollinated varieties BARI Begun-1 (Uttara), BARI Begun-4 (Kazla), BARI Begun-5 (Nayantara) and BARI Begun-6 (ISD006) and released as BARI Bt Begun-1, BARI Bt Begun-2, BARI $B t$ Begun-3 and BARI $B t$ Begun- 4 , respectively.

\subsection{Yield}

On average $B t$ eggplant varieties produced 23.21 tons fresh eggplant per hectare against 20.19 ton per hectare in non-Bt eggplant. This difference was smaller than that found in prior on-farm $B t$ eggplant trials in Bangladesh, although the smaller difference in this study might be due to higher fertilizer use on the non- $B t$ eggplant fields and difficulty in separating marketable from non-marketable produces through recall survey methods. Among the $B t$ varieties, BARI $B t$ Begun-2 gave the highest yield (26.0 t/ha) followed by BARI $B t$ Begun-4 (22.68 t/ha) and BARI $B t$ Begun-3 (21.10 t/ha) (Table 7). The lowest fresh yield of $B t$ 
varieties was obtained from BARI $B t$ Begun-1 (17.68 t/ha), likely due to its susceptibility to bacterial wilt. Among the non- $B t$ varieties, BARI Begun-4 (Kazla) produced the highest fruit yield (23.52 t/ha) followed by BARI Begun-6 (ISD006) (18.19 t/ha) and BARI Begun-5 (Nayantara) (17.77 t/ha). The lowest fresh yield of non- $B t$ varieties was recorded from BARI Begun-1 (Uttara) (14.39 t/ha). Among the regional locations, $B t$ eggplant planted in Rajshahi districts produced the highest fresh eggplant yield (25.76 t/ha) closely followed by Barisal (24.47 t/ha) and Rangpur (23.64 t/ha). The lowest yield was obtained from Khulna (20.12 t/ha). Similar yield results by location were observed for the non$B t$ varieties.

Comparing actual and percent yield differences across all locations, the largest difference (19\%) was recorded between BARI Bt Begun-1 and BARI Begun-1 (Uttara) (Table 8). About $10 \%$ yield difference was found between BARI $B t$ Begun-2 and BARI Begun-4 (Kazla), about 16\% for BARI $B t$ Begun-3 and BARI Begun-5, and about $17 \%$ for BARI-Bt Begun 4 and Bari-Begun-6.

Table 8. Yield difference between $B t$ and non-Bt eggplant varieties during winter 2016-17 in the study areas

\begin{tabular}{l|c|c|c}
\hline \multicolumn{1}{c|}{ Variety } & Yield (t/ha) & $\begin{array}{c}\text { Difference in yield between } \\
\boldsymbol{B} \boldsymbol{t} \text { and non-Bt varieties } \\
(\mathbf{t} / \mathbf{h a})\end{array}$ & $\begin{array}{c}\text { Yield difference } \\
(\boldsymbol{\%})\end{array}$ \\
\hline BARI Bt Begun-1 & 17.68 & 3.29 & 18.61 \\
BARI Begun-1 (Uttara) & 14.39 & & \\
BARI Bt Begun-2 & 26.00 & 2.48 & \\
BARI Begun-4 (Kazla) & 23.52 & & 15.78 \\
BARI Bt Begun-3 & 21.10 & 3.33 & \\
BARI Begun-5 & 17.77 & & 16.62 \\
(Nayantara) & & 3.77 & \\
BARI Bt Begun-4 & 22.68 & & \\
BARI Begun-6 (ISD006) & 18.91 & & \\
\hline
\end{tabular}

\subsection{Gross and net returns}

Gross returns from $B t$ eggplant cultivation was Tk. 394,570/ha as compared to Tk. 312,945/ha for non- $B t$ eggplant (Table 9). Net returns per hectare were Tk. 179,602/ha for $B t$ eggplant as compared to Tk. 29,841/ha for non-Bt eggplant (5 times larger for $B t$ eggplant farmers). The yield difference between the two groups was only 3.02 tons, but the non- $B t$ farmers applied almost three times more pesticides to maintain the yields as well as more fertilizer. Pesticide costs were Tk. 14215/ha for $B t$ eggplant and $T k$. 36,057for non-Bt eggplant. Therefore, the higher net returns for $B t$ eggplant as compared to non- $B t$ eggplant was due more to lower production costs than to higher yields. On the basis of total cost, 
production cost per kilogram of Bt eggplant was Tk. 9.26 and for non-Bt eggplant it was Tk. 14.20. On the basis of variable cost, production cost per kilogram of $B t$ eggplant was Tk. 6.29 and for non-Bt eggplant it was Tk. 10.47.

Table 9. Per hectare return from eggplant production in the study areas

\begin{tabular}{l|c|c}
\hline \multirow{2}{*}{\multicolumn{1}{c}{ Items }} & \multicolumn{2}{c}{ Return (Tk./ha) } \\
\cline { 2 - 3 } & Bt eggplant & Non-Bt eggplant \\
\hline Fresh eggplant yield (ton/ha) & 23.21 & 20.19 \\
Gross return & 394570 & 312945 \\
Gross margin & 248651 & 101590 \\
Net return & 179602 & 29841 \\
Benefit cost ratio & 1.84 & 1.11 \\
Production cost (Tk./kg): & & \\
Total cost basis & 9.26 & 14.02 \\
Variable cost basis & 6.29 & 10.47 \\
\hline
\end{tabular}

\section{Impact of $B t$ Technologies on Input Use, Productivity and Profitability}

$B t$ technology have some more advantages in brinjal cultivation compared to the conventional method (non- $B t$ ) of cultivation in terms of efficient inputs-use, cost saving and higher profitability. The impacts of $B t$ technologies on input use, crop yield and farm profitability are discussed in the following sections.

\subsection{Eggplant cultivation}

The $B t$ farmers in the study areas saved cost $22 \%$ in human labour, $20 \%$ mechanical power, $19 \%$ seedling, $28 \%$ organic fertilizer, $29 \%$ chemical fertilizer and $25 \%$ irrigation than that of non- $B t$ farmers. It was also interesting that $B t$ farmers saved money $61 \%$ from pesticides application than that of non- $B t$ farmers in the study areas (Table 10).

The productivity of a crop depends on many factors such as time of sowing, seed quality, variety, crop management, weather, rate of manure and fertilizer use and so on. However, the adopters of $B t$ technologies received $13 \%$ higher yield compared to non- $B t$ farmers. There was the higher selling price of $B t$ eggplant, the $B t$ farmers in the study areas obtained significantly higher gross $(21 \%)$ and net income (83\%) compared to non- $B$ farmer which was because of higher yield. The benefit cost ratio over total cost was also more than $13 \%$ higher for $B t$ farmers (Table 11). The total variable cost (VC) and fixed cost (FC) were also lower for $B t$ farmers compared to non- $B t$ farmers, respectively. 
Table 10. Input cost saving in eggplant cultivation by $B t$ farmers over non-Bt

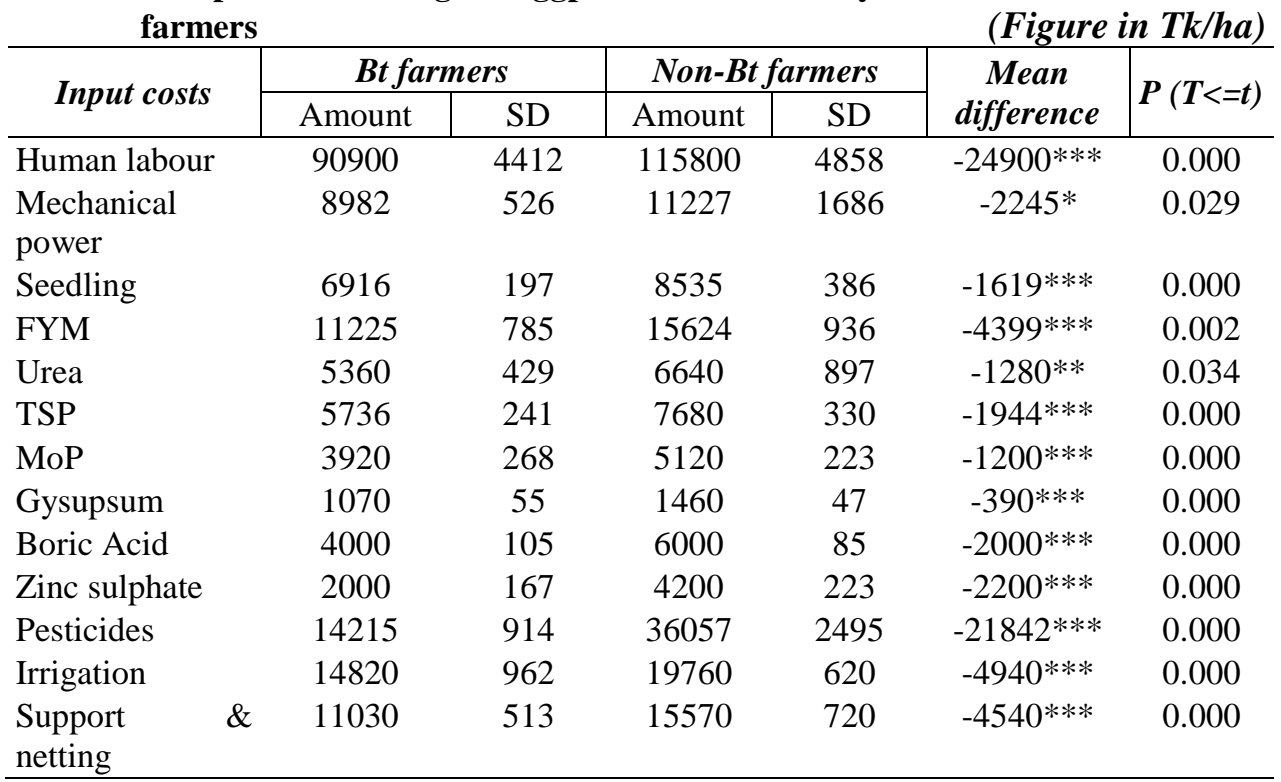

Note: Figures with negative sign in mean difference column indicate the costs saving by Bt farmers over non-Bt farmers, while non-negative figures indicate additional cost.

'***', '**' and '*' indicate significant at 1\%, 5\% and $10 \%$ level.

Table 11. Profitability differential in eggplant cultivation by $B t$ farmers vs. non-Bt farmers

(Figure in Tk/ha)

\begin{tabular}{|c|c|c|c|c|c|c|}
\hline \multirow{2}{*}{ Particulars } & \multicolumn{2}{|c|}{ Bt farmers } & \multicolumn{2}{|c|}{ Non-Bt farmers } & \multirow{2}{*}{$\begin{array}{c}\text { Mean } \\
\text { difference }\end{array}$} & \multirow{2}{*}{$P(T<=t)$} \\
\hline & Amount & SD & Amount & SD & & \\
\hline \multicolumn{7}{|l|}{ A. Returns } \\
\hline Yield (t/ha) & 23.21 & 6.33 & 20.19 & 4.23 & $3.02 * * *$ & 0.000 \\
\hline Gross return & 394570 & 1727 & 312945 & 1387 & $81625^{* * *}$ & 0.000 \\
\hline Gross margin & 248651 & 1756 & 101590 & 1532 & $14706^{* * *}$ & 0.000 \\
\hline Net return & 179602 & 2291 & 29841 & 3894 & $149761 * * *$ & 0.000 \\
\hline \multicolumn{7}{|l|}{ B. Cultivation cost } \\
\hline Fixed cost (FC) & 69049 & 2558 & 71749 & 1840 & -2700 & 0.142 \\
\hline Variable cost (VC) & 145919 & 827 & 211355 & 1970 & $-65436 * * *$ & 0.000 \\
\hline Total cost (TC) & 214968 & 1136 & 283104 & 4048 & $-68136 * * *$ & 0.000 \\
\hline \multicolumn{7}{|c|}{$\begin{array}{l}\text { C. Benefit cost ratio } \\
(\text { BCR })\end{array}$} \\
\hline Over VC & 2.70 & 0.017 & 1.48 & 0.011 & $1.22 * * *$ & 0.000 \\
\hline Over TC & 1.84 & 0.014 & 1.11 & 0.015 & $0.73 * * *$ & 0.000 \\
\hline
\end{tabular}

Note: Figures with negative sign in mean difference column indicate the amount saving Bt farmers over non-Bt farmers, while non-negative figures indicate additional amount.

'***', '**' and '*' indicate significant at 1\%, 5\% and $10 \%$ level. 


\subsection{Bt trait valuation:}

The $B t$ trait valuation was carried out using Partial Budgeting Analysis (PBA). The results of partial budgeting analysis for the introduction of $B t$ eggplant in the place of non-Bt eggplant cultivation by the adopters is given in Table 12 .

Table 12. Partial budget analysis of producing $B t$ eggplant instead of non-Bt

\begin{tabular}{l|l|l|l|c}
\hline $\begin{array}{c}\text { Sl. } \\
\text { no. }\end{array}$ & $\begin{array}{c}\text { Benefits due to adoption } \\
\text { of } \boldsymbol{B} \boldsymbol{t} \text { eggplant }\end{array}$ & Tk./ha & $\begin{array}{c}\text { Costs due to adoption } \\
\text { of } \boldsymbol{B} \boldsymbol{t} \text { eggplant }\end{array}$ & Tk./ha \\
\hline A. & $\begin{array}{l}\text { Increase in income (Added } 81625.00 \\
\text { income) }\end{array}$ & Added costs & 0.00 \\
B. & Reduction in costs & 68136.00 & Reduction in income & 0.00 \\
& Sub total & 149761.00 & Sub total & 0.00 \\
\hline
\end{tabular}

Net change in income per hectare due to adoption of $B t$ eggplant is Tk. 149761.00. Thus, the value of $B t$ trait in $B t$ eggplant is estimated at Tk. 149761.00.

\section{Conclusion}

The cultivation of non- $B t$ eggplant requires more inputs, especially pesticides, as compared to $B t$ eggplant. Because $B t$ farmers were guided by scientists to use proper inputs. But the non- $B t$ farmers used inputs as of their own choice. On an average, the non- $B t$ eggplant farmers applied insecticides 41 times during the crop life period and the $B t$ eggplant farmers applied insecticides only 11 times for controlling sucking pests. This pesticide use difference is an important factor affecting costs and returns to $B t$ eggplant as well as the human health and environmental advantage of $B t$ over non- $B t$ eggplant. It is likely that the actual marketable yield difference was greater than that was reported because FSB reduces eggplant marketability and non-Bt eggplant had more internal damage to the fruits (100\% of the non- $B t$ farmers experienced damage by FSB but $0 \%$ of the $B t$ farmers experienced such damage). It was observed that $B t$ eggplant fields were free not from FSB infestation either had the infestation ranging from $0.27 \%$ to $3.88 \%$ (shoot) and $0.21 \%$ to $4.17 \% \%$ (fruit). Therefore, application of pesticides reduced remarkably and economic benefit of the farmers increased significantly. The experience with $B t$ eggplant technology was good for most of the locations and up to the mark as reported by the $B t$ respondents. The cost for pesticides in producing eggplant could be substantially reduced by adopting $B t$ technology. The study clearly indicates huge potential for $B t$ eggplant to provide major environmental and economic benefits not only for farmers but for consumers. Hence the technology is environment friendly.

\section{Recommendations}

Based on the study findings, some policy recommendations are as follows:

$>$ More awareness among farmers about the $B t$ eggplant variety should be created through application of ICT. 
Extension personnel at all levels and progressive farmers should be trained in the cultivation of $B t$ eggplant on priority basis.

$>$ More awareness may be created among the traders and consumers about the benefits of $B t$ technology so that barriers to consumption may be circumvented

$>$ National research agencies may strengthen research on GMO crops to improve pesticides resistance, weedicides resistance and nutritional improvement of various crops. They may develop international collaboration in bio-technological research to avoid time lag in brining at new products.

$>$ Proper pesticide should be screened to effectively control sucking pest that attack $B t$ eggplant starting from seedling stage.

$>$ For getting higher yield and economic benefits, in the course of technology dissemination, the importance of good production practices must be emphasized.

$>B t$ technology should be introduced on locally popular other commercial eggplant varieties.

Acknowledgement: The authors are grateful to ABSP-II led by Cornell University for providing necessary financial support for the study.

\section{References}

ABSP-II. 2007. Fruit and Shoot Borer Resistant Eggplant-Fact Sheet, Cornell University Newsletter, Agricultural Biotechnology Support Project II, South Asia, July 2007.

ABSP-II. 2014. Fruit and Shoot Borer Resistant (FSBR)/Bt eggplant, Agricultural Biotechnology Support Project II, Cornell University. Available at: http://absp2.cornell.edu/projects/intersect.cfm?productid=2\&countryid=4

Alam, S.N.; M.A. Rashid, F.M.A. Rouf, R.C. Jhala, J.R. Patel, S. Satpathy, T.M. Shivalingaswamy, S. Rai, I. Wahundeniya, A. Cork, C. Ammaranan and N.S. Talekar. 2003. Development of an integrated pest management strategy for eggplant fruit and shoot borer in South Asia.Technical Bulletin No. 28, AVRDC Publication No.03-548, AVRDC-the World Vegetable Center, Shanhua, Taiwan, 2003.

BARI. 2014. Krishi Projukti Hatboi (Hand book on Agricultural technology), Bangladesh Agricultural Research Institute, Gazipur.

BBS. 2013. Yearbook of Agricultural Statistics, Bangladesh Bureau of Statistics.

BBS. 2014. Yearbook of Agricultural Statistics, Bangladesh Bureau of Statistics.

Choudhary, B. and K. Gaur. 2009. The development and regulation of Btbrinjal in India (eggplant/aubergine). ISAAA Brief No. 38, International Service for the Acquisition of Agri-Biotech Applications (ISAAA), Ithaca, NY, USA. Available at: http://www.isaaa.org/Resources/Publications/briefs/38/default.htm! 
Choudhary, B, K.M. Nasiruddin and K. Gaur. 2014. The status of commercialized Btbrinjal in Bangladesh. ISAAA Brief No. 47, International Service for the Acquisition of Agri-Biotech Applications (ISAAA), Ithaca, NY, USA.

Chowdhury, M.A.H. and M.S. Hassan 2013. Handbook of Agricultural Technology, Bangladesh Agricultural Research Council (BARC), Farmgate, Dhaka, Bangladesh, May 2013.

FAO. 2013. FAO Country profile-Bangladesh, the Food and Agricultural Organization (FAO) Rome, Italy.

Meherunnahar, M. and D.N.R. Paul. 2009. Bt. brinjal: Introducing genetically modified brinjal (eggplant/aubergine) in Bangladesh. BDRWPS No. 9, Bangladesh Development Research Working Paper Series, Bangladesh Development Research Center (BDRC), October 2009.

Rahman, M.M., M.R. Ali and M.S. Hossain. 2009. Evaluation of combined management options for managing brinjal shoot and fruit borer. Academic Journal of Entomology, 2 (2): 92-98.

Saifullah, M., M.A. Guffar; S. Ahmad and M.A.J. Bhuya. 2012.Utilization of indigenous vegetables for sustainable vegetable production in Bangladesh. International Symposium on Sustainable Vegetable Production in Southeast Asia, Salatiga, Indonesia, August 2012.

World Bank. 2011. Bangladesh Integrated Agricultural Productivity Project, World Bank, June 2011.Committee on the Impact of Biotechnology on Farm-Level Economics and Sustainability, The Impact of Genetically Engineered Crops on Farm Sustainability in the United States, National Research Council, National Academies Press, Washington, D.C. 2010. 
